\title{
Bio immune(G)en medicine in allergic diseases especially asthma
}

\author{
Gilbert Glady \\ From 3rd WAO International Scientific Conference (WISC) 2014 \\ Rio de Janeiro, Brazil. 6-9 December 2014
}

\section{Background}

Bio Immune(G)en Medicine is a diagnostic and therapeutic method representing a new immunomodulating way of approaching the asthmatic disease.

\section{Methods}

To reach diagnosis this method uses a wide range of biological parameters providing a great deal of significant information in the context of allergy such as lymphocyte typing and protein profiles or the Th1/Th2 differentiation, as well as many bacterial and viral serologies, to substantiate the biological diagnosis and guide the therapeutic result.

Within this therapy, numerous immune-competent signaling molecules are used, especially microRNAs representing actually one of the best known epigenetic process, which are prepared according to the homeopathic dilution-dynamisation mode to ensure total safety in terms of any adverse side-effects.

\section{Results}

This allows developing of a biomimetic and holistic immune therapy involving the neutralization of certain microbial agents, of which regulatory, medium-to-longterm effects are proving to be extremely beneficial to patients in a large number of allergic diseases.

\section{Conclusions}

The description of some clinical cases of asthma will help to highlight the way in which this innovative method links with effectiveness the findings of basic research to human clinic and therapeutics.

Published: 8 April 2015

\section{EBMA, France}

doi:10.1186/1939-4551-8-S1-A58

Cite this article as: Glady: Bio immune(G)en medicine in allergic diseases especially asthma. World Allergy Organization Journal 20158 (Suppl 1):A58.
Submit your next manuscript to BioMed Central and take full advantage of:

- Convenient online submission

- Thorough peer review

- No space constraints or color figure charges

- Immediate publication on acceptance

- Inclusion in PubMed, CAS, Scopus and Google Scholar

- Research which is freely available for redistribution 